\title{
Results Validation about the Adoption Model of Information and Communication Technologies Applied to the Technical University of Cotopaxi.
}

\author{
JUAN CARLOS CHANCUSIG CHISAG ${ }^{1,2}$ \\ Faculty of Postgraduate Programs in Systems and Computing \\ ${ }^{1}$ National University Mayor San Marcos \\ Lima, PERU \\ 2 Technical University of Cotopaxi \\ Latacunga, ECUADOR \\ JAVIER ARTURO GAMBOA CRUZADO,3,1 \\ Faculty of Systems and Informatics \\ ${ }^{3}$ Autonomous University of Peru \\ Lima, PERU \\ ${ }^{1}$ Universidad Nacional Mayor San Marcos \\ Lima, PERU
}

\begin{abstract}
Within the last years, the utilization of ICT has developed within the different education levels and particularly in universities that these count with new technological resources much advanced within the particular case of the university during which the investigation is developing the study is, to enhance the Educational Learning process implementing a replacement adoption model of ICT, with which it's possible to offer a solution to the educational process. A methodology is realized of study supported the systematical Review of the literature of the models of the ICT citing as an example the primary model that there appeared the Model TAM who was developed by [1] and of the Web 2 and Web 3 and therefore the ICT within the Universities of the planet. The investigation threw the results expected with the creation of the new model of adoption of ICT, with the utilization of collaborative hardware during a Learning Environment (CLE) for creating the constructs, alpha of Cronbach, variance, and interrelations and therefore the use of statistical software because the Minitab validated the raised hypotheses. Educational Technologies are very important nowadays for the Development of each country.
\end{abstract}

Key words: - Development, Learning, collaborative work, interactivity, communication, e-learning, MOOC, education.

Received: June 2, 2019. Revised: January 13, 2020. Accepted: February 4, 2020. Published: February 21, 2020.

\section{Introduction}

Innovation is linked with qualified education, so it's essential to use principles that align the efforts of an educational system that will be privileged. For this, researchers emphasize the following principles that are related with ICT: a) Dynamic learning, b) Collaborative learning, c) Autonomous education, d) Interactivity at various levels, e) Synchronous and asynchronous communication, f) Relevant and creative content, and g) Continuous evaluation [2]. Within the process of technological integration, researchers can discover three key actors whose collaboration is essential so that it is successfully established: students, public administrations, and teachers [3].
Nowadays, the use of ICT tools such as laptops, electronic pads, smartphones, along with the broadband Internet, interactive Web 2.0 technologies and cloud computing applications, have improved both teaching and learning in educational institutions [4]. Thanks to the rapid development of ICT, web-based LMS systems reached companies, which made it possible to access web-based content (e-learning 1.0 support). These systems were followed by new LMS that support active learning (e-learning 2.0), based on the web of reading and writing. They opened new possibilities, such as chat, forum, wiki, e-portfolio, and workgroup [5]. Something interesting is the proposal of the Sakai system with the Collaborative 
Learning Environment (CLE), which is a system developed in EBTIC according to [6] that has tools and functionalities that allow communication and collaborative creation of instruments within the same virtual environment. Regarding [7] "Information Technology (IT) has become an omnipresent and crucial element to support, provide sustainability, and facilitate the growth of the business of any organization." So researchers deduce that the environment becomes more dynamic and comprehensive in organizations and, of course, in universities, which is generated by significant technological changes. The primary function of ICT inside the classroom is to facilitate teaching-learning, and they are means to optimize teaching-learning methodologies and support to reform communication and collaboration either in person or online. Web 3.0 is the common designation of the Internet since its evolution admitted the change of web pages, where the interested party goes from a passive to an active role and actively favors the construction of virtual learning spaces [8]. The digital era increasingly demands that universities face new challenges by combining the use of mobile devices [9], with teaching curricular elements that are more typical of traditional education systems. The objective in this regard is to promote and encourage the development and application of skills, languages, spaces, and times that are emerging in the field of technology through dynamic forms of learning that positively affect the education processes of students [9], [10], [11].

\section{State of the Art}

From previous studies, reference is made to the functionalities within mobile education, because of the portability, interactivity, and content of these innovative technologies, which collaborates in learning, originates cooperation [12], [13]. The collection of data on learning activities towards students is identified as a success factor in mixed courses, and it is a crucial point towards the application of observations to inform content selection, course design, and learning pathways [14]. Learning collectively is when accessing resources using ICT, with a focus on the teaching and learning process is usually called online learning [15]. In e-learning environments, the distribution and delivery of courses and educational activities are managed through software applications, more particularly, with a Learning Management System (LMS). A more common functional description of a Learning Management Systems (LMS) is the primary use for online or blended learning. The functions of these systems include supporting the distribution of course materials online, associating students with courses, monitoring student performance, storing student work, and mediating communication between student-teachers systemically [16].

The researcher [17], mentions some of the vital Web 2.0 tools that the LMS environment must have as fundamental characteristics, for teachinglearning:

- Content distribution tools. Teachers must provide an area for the student to have the information systematically in the form of files and folders that can have different formats (HTML, PDF, TXT, ODT, XLSX, $P N G$...) and must have metadata to present content and information: links to online archives, web pages, calendars, labels with various elements (text, images, presentations, videos).

- Synchronous and asynchronous communication-collaboration tools: so that individuals in a training activity have to communicate and work regularly, such as exchange of discussion forums and exchange of information, group chat rooms, news, calendar, course messaging, wikis, among others.

- Performance and evaluation tools: as editable questionnaires by the teacher for student evaluation and instant marks about individual and group tasks, for the teacher reports on the activity of each student.

- Management tools and user profile assignments that allow assigning permissions within each course to be taught, access management. These means can be done at the administrator level, but also at the tutor level and student level.

- Additional tools: Some platforms have a portfolio, syllabus, notebook, search systems within the course, and/or forums, among others, depending on the LMS to be used and the platform compatibility.

In our research, there are several examples of LMS such as WebCT, Moodle, Black Board, Moodle, Whiteboard, Web Board, Web Course in a Box, Claroline, Net Campus, Phoenix Pathlore, Profe, Saba, Symposium, Angel, Sakai, and Moodle, among others. 
Currently, LMS can be of three types: commercial use (or proprietary), free software, and in the cloud explains the author [18].

1. Proprietary: They are generally safe platforms with many features that can be transmitted according to the needs and budget that the company needs, and this has higher costs and expenses. Among the best known are Blackboard, Fronter, OS Media, eCollege, Sid Web, Educative, Saba, WebCT, and Catedra, among others.

2. Free Software: They were born as an alternative to generating fewer costs and expenses, an online training project. These LMS are developed by educational institutions or subjects that are linked to education. Some of these platforms are Open Source, admitting that the user is free to handle that software. Among the most used are ATutor, Claroline, Dokeos dot LRN, Ganesha, ILIAS, Moodle and Sakai.

3. In the cloud: They are not considered LMS platforms themselves because their most significant utility is to allow support to the classroom, as well as the development of MOOC (Massive Open Online Courses). The most popular are Coursera, Ecaths, Edmodo, edX, Miriadex, Udacity, Udemy, Wiziq, among others.

Therefore, LMS are systems through which teaching-learning processes can be managed through the systematic use of Web 2.0 and Web 3.0 tools, either for virtual or online training and also as an instrument of support for traditional teaching, where the student is the interpreter of the learning process [19].It must be taken into account that a virtual learning environment is related to interactive design, which certifies its use so that, the creation of content and learning activities is carried out in a productive and personalized way where a type of assessment is set to be taken by students [20].

- MOOC: Massive Open Online Courses (MOOC) was introduced in Canada by [21] which coined the acronym to distinguish it from an online course developed by George Siemens and Stephen Downes. The course entitled Connectivism and Connective Knowledge was prepared by 25 students who paid their tuition and got their degree. However, it was followed free of charge and without accreditation by 2300 students and the general public via the Internet using ICT [22]. Despite the acceptance of using MOOCs, the trainees of these courses consider locating severe problems, which generates high dropout indicators. Recent research revealed that only $4 \%$ of students who enrolled in a Coursera MOOC completed their courses [23].

- PLE (Personal Learning Environment): PLEs refer to how a person organizes his/her personal relationships, web tools and information for self-learning [24].

- Cloud computing: It is a cloud service that contains tools, applications, or managers remotely from the Internet itself [25]. The great advantage of this Web 2.0 technology is the possibility of accessing these files from any connection point that connects to the Internet valid for an account [26].

- Social networking: They are presented as a simple element and zero costs to put teachers and students in contact with each other since they can be used several uses according to educational learning activities [27]. The students who are involved and know social networks perfectly, developing education in this space, is a way to penetrate sites that are already well known to them. So it is essential to take advantage of this resource efficiently to deliver content and learning tasks to the student [28].

- 3D Technologies: The development of 3D virtual worlds in the educational field allows new teaching-learning methods to be brought together in an educational environment where students can interact and validate activities [29]. 3D virtual worlds have the functionalities to customize our physique technically in three dimensions. Objects can be established and managed within the virtual world, and adequately represented sites can be developed where individuals can interact with each other, with objects, or with their work environment. [30]

So, Web 3.0 is an evolution of Web 2.0, and for that reason, it is essential to represent Web 3.0 as a service that offers more personalized learning, formed the student's previous knowledge, skills, motivations, and abilities, the activities are shown according to the progress in the training they require. Personalized learning shows only really 
selected information for the student, in an appropriate way, and especially at the right time [31].

\section{Methodology}

From the perspective of the type of reasoning used, deductive and inductive methods can be used, based on this categorization, this investigation can be considered deductive.

\section{Population}

In the Technical University of Cotopaxi, there is a population of 10385 students enrolled in the different faculties dated September 17, 2019.

\section{Sample}

"It is a process in which the probability of each element of integrating the sample is known [32].

In this research project on academic software, probabilistic, or random sampling will be used, because the probability of each element that integrates the sample is known.

\section{Identification of the hypotheses of the proposed theoretical model}

These hypotheses are oriented to basic research.

Table 1. Hypothesis for basic research of the proposed theoretical model CMAT

\begin{tabular}{|l|l|}
\hline Hypothesis & $\begin{array}{l}\text { Description regarding the } \\
\text { Collaborative Learning Environment } \\
\text { system (CLE) }\end{array}$ \\
\hline H1.A & $\begin{array}{l}\text { The Expectation of Performance has } \\
\text { a positive impact on Perceived } \\
\text { Utility. } \\
\text { Perceived Entertainment has a } \\
\text { positive impact on Perceived Utility. } \\
\text { The Social Factor has a positive } \\
\text { impact on Perceived Utility. } \\
\text { H3.A }\end{array}$ \\
H4.A & $\begin{array}{l}\text { The Facilitating Condition has a } \\
\text { positive impact on the Perceived } \\
\text { Utility. } \\
\text { Teamwork has a positive impact on } \\
\text { Perceived Utility. } \\
\text { Teamwork has a positive impact on } \\
\text { Perceived Ease of Use. }\end{array}$ \\
H5.A & \\
\hline
\end{tabular}

\begin{tabular}{|l|l|}
\hline H6.A & $\begin{array}{l}\text { Technical Support has a positive } \\
\text { impact on Perceived Utility. } \\
\text { Technical Support has a positive } \\
\text { impact on Perceived Ease of Use. } \\
\text { Computational Self-Efficiency has a } \\
\text { positive impact on Perceived Utility. } \\
\text { Computational Self-Efficiency has a } \\
\text { positive impact on Perceived Ease of } \\
\text { Use. } \\
\text { H7.B }\end{array}$ \\
H8perience has a positive impact on \\
the Ease of Perceived Use. \\
H9.A
\end{tabular}

Elaborated by the author

\section{Identification of the variables of the proposed theoretical model}

Now, it is necessary to define the new model proposed, which uses TAM as the base model, which also includes variables or factors focused on Collaborative Learning Support Systems aimed at university students, the variables already considered in the known extensions of TAM are also added, Like TAM2, TAM3 and UTAUT, in this doctoral work it is proposed that PU (Perceived Utility), PEOU (Perceived Ease of Use) influence $\mathrm{BI}$ (Intention of Use) and this last factor determines the AU (System Use). For the construction of the model, other existing solutions have been studied and analyzed, extracting some factors and variables that were considered necessary for the context in which the proposed model is focused. The systematic review of the literature of the TAM 
model and its variants made it possible to verify the explanatory capacity of the initial Davis study (1989b), since significant relationships were found between PU, PEOU, AU, and BI in the use of elearning.

The external variables systematically reviewed that adapt to predict the Collaborative Learning Environment (CLE) system with the Sakai software, directed towards the students to be used in this new model are, as it is shown in Figure 12, schematically:

\section{Data collection}

The data were collected through a Likert questionnaire that was filled out during class hours by students enrolled at the Technical University of Cotopaxi (UTC).

To carry out this study, two different surveys have been carried out, one of them aimed at blog users and the other aimed at wikis users in a corporate environment. The sample has been taken during February, March, April, May, and June of 2019.

\section{Measurement scale}

The scale used to measure usage comes from Kwon and Wen (2010). All items were scored on a 5point Likert scale $(1=$ Strongly disagree; $5=$ Strongly agree), except those referring to personal information variables and others related to the use of the Internet that will be used to perform a descriptive analysis.

This scale is ordinal and is characterized by using a set of expressions on an agreement/disagreement scale. Its main advantage of using this scale is that all participants in this research share the order of expressions, and the values of the scale have an easy to understand relationship for the participants.

Table 2. Likert scale used in the items of factors except for personal and Internet use Sarabia (1999).

\begin{tabular}{|c|c|c|l|l|}
\hline 1 & 2 & 3 & 4 & \multicolumn{1}{|c|}{5} \\
\hline TOTALLY & Partiall & Neither & Partiall & Totall \\
DISAGRE & $\mathrm{y}$ & agree & y agree & $\mathrm{y}$ \\
$\mathrm{E}$ & disagre & nor \\
& $\mathrm{e}$ & $\begin{array}{c}\text { disagre } \\
\mathrm{e}\end{array}$ & & agree \\
& & & \\
\hline
\end{tabular}

Elaborated by the author

The elaboration of the questions that compose the survey (items), researchers have tried to use those scales that have already used and validated in the review of the literature carried out in chapter 2, adapting them to the Sakai CLE system. The following table summarizes the measuring instrument used in the empirical study corresponding to the acceptance and use of the Sakai CLE system.

Table 3 Summary of the measurement instrument used in the Sakai CLE system questionnaire.

\begin{tabular}{|c|c|c|}
\hline Variables & Code & Question \\
\hline \multirow{3}{*}{$\begin{array}{l}\text { Performance } \\
\text { Expectation (PE): } \\
\text { It is the interest to } \\
\text { improve their } \\
\text { performance } \\
\text { when using the } \\
\text { Sakai } \\
\text { system CLE } \\
\text { carrying when } \\
\text { learning } \\
\text { activities. }\end{array}$} & PE1 & Using the Sakai CLE system increases my performance in classes. \\
\hline & PE2 & $\begin{array}{l}\text { Using the Sakai CLE system applied in my studies increases my } \\
\text { efficiency. }\end{array}$ \\
\hline & PE3 & $\begin{array}{l}\text { Using the Sakai CLE system allows me to complete my university } \\
\text { tasks faster. }\end{array}$ \\
\hline \multirow{3}{*}{$\begin{array}{l}\text { Perceived } \\
\text { Entertainment } \\
\text { (PP): Includes } \\
\text { individual } \\
\text { pleasure, } \\
\text { psychological } \\
\text { stimulation and } \\
\text { interests, it is the }\end{array}$} & PP1 & $\begin{array}{l}\text { I think that when using the Sakai CLE system the qualification is } \\
\text { fairer. }\end{array}$ \\
\hline & & \\
\hline & PP2 & I find the Sakai CLE system entertaining. \\
\hline
\end{tabular}




\begin{tabular}{|c|c|c|}
\hline 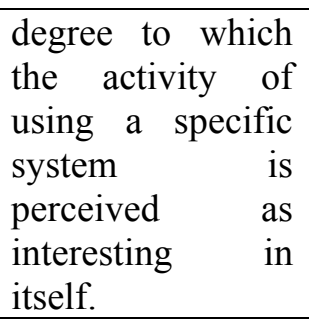 & PP3 & $\begin{array}{l}\text { I like to use the Sakai CLE system for collaborative activities at the } \\
\text { university. }\end{array}$ \\
\hline \multirow{3}{*}{$\begin{array}{l}\text { Social Factor } \\
\text { (SF): Influence } \\
\text { exerted on the } \\
\text { student by those } \\
\text { individuals who } \\
\text { are benchmarks } \\
\text { for him in the } \\
\text { field of learning. }\end{array}$} & SF1 & $\begin{array}{l}\text { Colleagues who influence my behavior believe that I should use the } \\
\text { Sakai CLE system to carry out collaborative activities. }\end{array}$ \\
\hline & SF2 & $\begin{array}{l}\text { There are teachers who make the use of the Sakai CLE system } \\
\text { useful to fulfill university tasks. }\end{array}$ \\
\hline & SF3 & $\begin{array}{l}\text { Important people to me think that I should use the Sakai CLE } \\
\text { system correctly. }\end{array}$ \\
\hline \multirow{3}{*}{$\begin{array}{l}\text { Facilitating } \\
\text { Condition (FC): It } \\
\text { is the level that } \\
\text { the university } \\
\text { student believes } \\
\text { that there is a } \\
\text { technological and } \\
\text { administrative } \\
\text { infrastructure that } \\
\text { supports the } \\
\text { system. }\end{array}$} & $\mathrm{FC1}$ & $\begin{array}{l}\text { The university has the adequate infrastructure to use the Sakai CLE } \\
\text { system. }\end{array}$ \\
\hline & $\mathrm{FC} 2$ & $\begin{array}{l}\text { He believes that teachers are trained to be able to teach through the } \\
\text { Sakai CLE system. }\end{array}$ \\
\hline & FC3 & $\begin{array}{l}\text { The support of the university community facilitates the learning of } \\
\text { the Sakai CLE system. }\end{array}$ \\
\hline \multirow{3}{*}{$\begin{array}{l}\text { Teamwork } \\
\text { (CTE): They are } \\
\text { the tasks done by } \\
\text { several students } \\
\text { where each one } \\
\text { does apart, but all } \\
\text { with a common } \\
\text { objective which is } \\
\text { to carry out the } \\
\text { learning } \\
\text { activities. }\end{array}$} & CTE1 & $\begin{array}{l}\text { Collaborative tasks flow better when performed in the Sakai CLE } \\
\text { system. }\end{array}$ \\
\hline & CTE2 & $\begin{array}{l}\text { The activities used in the Sakai CLE system will give better results } \\
\text { than solving them individually. }\end{array}$ \\
\hline & CTE3 & $\begin{array}{l}\text { Using the Sakai CLE system will increase the number of } \\
\text { interactions between students and teachers. }\end{array}$ \\
\hline \multirow{3}{*}{$\begin{array}{l}\text { Technical Support } \\
\text { (TS): Physical } \\
\text { resources and } \\
\text { adequate } \\
\text { personnel to help } \\
\text { users to solve } \\
\text { problems related } \\
\text { to computers, e- } \\
\text { mail and by } \\
\text { phone. }\end{array}$} & TS1 & $\begin{array}{l}\text { The Sakai CLE system provides help when there is a technical } \\
\text { problem. }\end{array}$ \\
\hline & TS2 & $\begin{array}{l}\text { Sakai CLE system support personnel have a positive predisposition } \\
\text { to help when consulted. }\end{array}$ \\
\hline & TS3 & $\begin{array}{l}\text { The Sakai CLE system offers frequently asked questions and } \\
\text { answers about its use. }\end{array}$ \\
\hline $\begin{array}{l}\text { Computational } \\
\text { Efficiency (CSE): } \\
\text { Confidence that }\end{array}$ & CSE1 & $\begin{array}{l}\text { I can complete collaborative activities in the Sakai CLE system if I } \\
\text { have not used a system with these characteristics. }\end{array}$ \\
\hline
\end{tabular}




\begin{tabular}{|c|c|c|}
\hline \multirow{2}{*}{$\begin{array}{l}\text { an individual } \\
\text { possesses of his } \\
\text { abilities to } \\
\text { perform well the } \\
\text { tasks and learning } \\
\text { activities when } \\
\text { using the Sakai } \\
\text { CLE system. }\end{array}$} & CSE2 & $\begin{array}{l}\text { I can complete collaborative activities in the Sakai CLE system if } \\
\text { someone else helps me with the induction of the system. }\end{array}$ \\
\hline & CSE3 & $\begin{array}{l}\text { I can solve most problems that arise when using the Sakai CLE } \\
\text { system if I try my best. }\end{array}$ \\
\hline \multirow{3}{*}{$\begin{array}{l}\text { Experience } \\
\text { (EXP): It means } \\
\text { having practice in } \\
\text { collaborative } \\
\text { learning activities } \\
\text { using the Sakai } \\
\text { CLE system. }\end{array}$} & EXP1 & He has experience using this type of collaborative system. \\
\hline & EXP2 & $\begin{array}{l}\text { He believes that teachers have the necessary experience to use the } \\
\text { Sakai CLE system. }\end{array}$ \\
\hline & EXP3 & $\begin{array}{l}\text { They believe that the authorities support this type of collaborative } \\
\text { system to improve education. }\end{array}$ \\
\hline \multirow{3}{*}{$\begin{array}{l}\text { Satisfaction } \\
\text { (SAT): In the } \\
\text { content under } \\
\text { study, satisfaction } \\
\text { is the extent to } \\
\text { which the Sakai } \\
\text { CLE system } \\
\text { meets its specific } \\
\text { and functional } \\
\text { requirements. }\end{array}$} & SAT1 & $\begin{array}{l}\text { You are satisfied with the functionality of the Sakai CLE system as } \\
\text { a collaborative learning tool. }\end{array}$ \\
\hline & SAT2 & The Sakai CLE system is efficient for the exchange of knowledge. \\
\hline & SAT3 & $\begin{array}{l}\text { I am satisfied with the different collaborative activities offered by } \\
\text { the Sakai CLE system. }\end{array}$ \\
\hline \multirow{3}{*}{$\begin{array}{l}\text { Perceived Utility } \\
\text { (PU): It is the } \\
\text { collaborative } \\
\text { perception that } \\
\text { the use of the } \\
\text { Sakai } \\
\text { system } \\
\text { contributes to } \\
\text { improving the } \\
\text { quality } \\
\text { education } \\
\text { students. }\end{array}$} & PU1 & The Sakai CLE system is useful for collaborative learning. \\
\hline & PU2 & $\begin{array}{l}\text { The Sakai CLE system is academically interesting for collaborative } \\
\text { learning. }\end{array}$ \\
\hline & PU3 & $\begin{array}{l}\text { The Sakai CLE system improves the effectiveness of the activities I } \\
\text { carry out. }\end{array}$ \\
\hline \multirow{3}{*}{$\begin{array}{l}\text { Perceived Ease of } \\
\text { Use (PEOU): It is } \\
\text { the collaborative } \\
\text { perception that } \\
\text { the use of the } \\
\text { Sakai CLE } \\
\text { system will be } \\
\text { effortless. }\end{array}$} & PEOU1 & The Sakai CLE system is easy to navigate. \\
\hline & PEOU2 & In the Sakai CLE system I quickly find the information I require. \\
\hline & PEOU3 & $\begin{array}{l}\text { The Sakai CLE system offers a friendly environment for } \\
\text { collaborative activities. }\end{array}$ \\
\hline $\begin{array}{l}\text { Intent to Use }(\mathrm{BI}) \text { : } \\
\text { This construct }\end{array}$ & BI1 & You would like to visit the Sakai CLE system frequently. \\
\hline
\end{tabular}




\begin{tabular}{|c|c|c|}
\hline \multirow{2}{*}{$\begin{array}{l}\text { adopts the } \\
\text { influence of } \\
\text { Perceived } \\
\text { Usefulness and } \\
\text { Perceived Ease of } \\
\text { Use and evaluates } \\
\text { the intention to } \\
\text { use the system. }\end{array}$} & BI2 & $\begin{array}{l}\text { Taking into account that I have access to the Sakai CLE system } \\
\text { from the university, I predict that I will use it the following } \\
\text { semester. }\end{array}$ \\
\hline & $\mathrm{BI} 3$ & $\begin{array}{l}\text { Assuming that you have access to the Sakai CLE system anywhere, } \\
\text { I intend to use it for my learning of the subjects taught. }\end{array}$ \\
\hline \multirow{3}{*}{$\begin{array}{l}\text { Use of the System } \\
\text { (AU): This factor } \\
\text { is influenced by } \\
\text { the Intent to Use } \\
\text { (BI) and values } \\
\text { the use of the } \\
\text { Sakai CLE } \\
\text { system. }\end{array}$} & AU1 & $\begin{array}{l}\text { The teacher proposes in the subject to use a reasonable time of } 3 \\
\text { hours to use the Sakai CLE system, you comply with it. }\end{array}$ \\
\hline & AU2 & $\begin{array}{l}\text { I frequently connect to the Sakai CLE system to find out the tasks } \\
\text { assigned by the teachers. }\end{array}$ \\
\hline & AU3 & $\begin{array}{l}\text { I enter the Sakai CLE system to interact in my learning activities at } \\
\text { least once a day. }\end{array}$ \\
\hline
\end{tabular}

Elaborated: By the Author

\section{Results}

The instrument to validate service quality and measure the use and acceptance of Information and Communication Technologies consists of 13 variable-questions: Performance Expectation (3 questions), Perceived Entertainment (3 questions), Social Factor (3 questions), Facilitating Condition (3 questions), Teamwork (3 questions), Technical Support (3 questions), Computational Selfefficiency (3 questions), Experience (3 questions), Satisfaction (3 questions), Perceived Usefulness (3 questions), Perceived Ease of Use (3 questions), Intent to Use (3 questions), Use of the System (3 questions).

Returns the following results:

Table 4: Results for the construction of the Model.

\begin{tabular}{|l|l|l|l|}
\hline Constructs & $\begin{array}{l}\text { Cronbach' } \\
\text { s Alpha }\end{array}$ & $\begin{array}{l}\text { Varianc } \\
\mathrm{e}\end{array}$ & $\begin{array}{l}\text { Correlation } \\
\mathrm{s}\end{array}$ \\
\hline Global Model & 0,948 & 1,282 & 0,346 \\
\hline $\begin{array}{l}\text { Performance } \\
\text { Expectation }\end{array}$ & 0,875 & 0,902 & 0,700 \\
\hline $\begin{array}{l}\text { Perceived } \\
\text { Entertainmen } \\
\text { t }\end{array}$ & 0,819 & 0,963 & 0,604 \\
\hline Social Factor & 0,595 & 1,391 & 0,334 \\
\hline $\begin{array}{l}\text { Facilitating } \\
\text { Condition }\end{array}$ & 0,563 & 1,633 & 0,332 \\
\hline Team work & 0,868 & 1,119 & 0,689 \\
\hline $\begin{array}{l}\text { Technical } \\
\text { support }\end{array}$ & 0,903 & 1,241 & 0,758 \\
\hline $\begin{array}{l}\text { Computation } \\
\text { al Self- }\end{array}$ & 0,484 & 1,256 & 0,257 \\
\hline
\end{tabular}

\begin{tabular}{|l|l|l|l|}
\hline Efficiency & & & \\
\hline Experience & 0,447 & 1,843 & 0,174 \\
\hline Satisfaction & 0,864 & 1,152 & 0,683 \\
\hline $\begin{array}{l}\text { Perceived } \\
\text { Profit }\end{array}$ & 0,894 & 1,047 & 0,739 \\
\hline $\begin{array}{l}\text { Perceived } \\
\text { Ease of Use }\end{array}$ & 0,901 & 1,219 & 0,753 \\
\hline Intent of Use & 0,839 & 1,045 & 0,637 \\
\hline $\begin{array}{l}\text { Use of } \\
\text { System }\end{array}$ & 0,883 & 1,848 & 0,717 \\
\hline
\end{tabular}

Elaborated: By the Author

\section{Individual reliability of the indicators}

To assess the individual reliability of each indicator, the load factor was observed from the confirmatory factor analysis (CFA), as defined in the methodology there are two indicators that cannot be considered reliable, their factor load is less than 0.707, in the Table, we can see the factor loads of all the constructs.

Table 5. Individual reliability of the indicators

\begin{tabular}{|l|l|l|l|l|}
\hline Constructs & $\begin{array}{l}\text { Hal } \\
\mathrm{f}\end{array}$ & $\begin{array}{l}\text { Standar } \\
\mathrm{d} \\
\text { deviatio } \\
\mathrm{n}\end{array}$ & $\begin{array}{l}\text { Factori } \\
\text { al Load }\end{array}$ & $\begin{array}{l}\text { Kaiser- } \\
\text { Meyer- } \\
\text { Olkin } \\
\text { Measur } \\
\mathrm{e}\end{array}$ \\
\hline $\begin{array}{l}\text { Performance } \\
\text { Expectation }\end{array}$ & $\begin{array}{l}3,9 \\
0\end{array}$ & 0,962 & 0,881 & 0,728 \\
\hline PE1 & $\begin{array}{l}4,0 \\
0\end{array}$ & 0,927 & 0,873 & \\
\hline PE2 & $\begin{array}{l}4,0 \\
8\end{array}$ & 0,961 & 0,759 & \\
\hline PE3 & & & & \\
\hline
\end{tabular}




\begin{tabular}{|c|c|c|c|c|}
\hline $\begin{array}{l}\text { Perceived } \\
\text { Entertainmen } \\
\mathrm{t}\end{array}$ & & & & 0,706 \\
\hline PE1 & $\begin{array}{l}3,7 \\
6\end{array}$ & 1,032 & 0,861 & \\
\hline PE2 & $\begin{array}{l}3,7 \\
8\end{array}$ & 0,958 & 0,765 & \\
\hline PE3 & $\begin{array}{l}3,9 \\
4\end{array}$ & 0,962 & 0,709 & \\
\hline Social Factor & & & & 0,634 \\
\hline SF1 & $\begin{array}{l}3,6 \\
9\end{array}$ & 1,078 & 0,633 & \\
\hline SF2 & $\begin{array}{l}3,3 \\
1\end{array}$ & 1,295 & 0,600 & \\
\hline SF3 & $\begin{array}{l}3,6 \\
8\end{array}$ & 1,155 & 0,505 & \\
\hline $\begin{array}{l}\text { Facilitating } \\
\text { Condition }\end{array}$ & & & & 0,527 \\
\hline FC1 & $\begin{array}{l}3,8 \\
5 \\
\end{array}$ & 1,257 & 0,999 & \\
\hline FC2 & $\begin{array}{l}3,3 \\
2 \\
\end{array}$ & 1,451 & 0,598 & \\
\hline FC3 & $\begin{array}{l}3,8 \\
0 \\
\end{array}$ & 1,102 & 0,850 & \\
\hline Team work & & & & 0,739 \\
\hline TW1 & $\begin{array}{l}3,8 \\
0\end{array}$ & 1,022 & 0,850 & \\
\hline TW2 & $\begin{array}{l}3,8 \\
5\end{array}$ & 1,012 & 0,837 & \\
\hline TW3 & $\begin{array}{l}3,8 \\
9\end{array}$ & 1,136 & 0,804 & \\
\hline $\begin{array}{l}\text { Technical } \\
\text { Support }\end{array}$ & & & & 0,738 \\
\hline TS1 & $\begin{array}{l}3,7 \\
5\end{array}$ & 1,142 & 0,936 & \\
\hline TS2 & $\begin{array}{l}3,7 \\
9 \\
\end{array}$ & 1,104 & 0,846 & \\
\hline TS3 & $\begin{array}{l}3,9 \\
0\end{array}$ & 1,097 & 0,831 & \\
\hline $\begin{array}{l}\text { Computation } \\
\text { al Self- } \\
\text { Efficiency }\end{array}$ & & & & 0,504 \\
\hline $\mathrm{CS} 1$ & $\begin{array}{l}3,9 \\
0\end{array}$ & 1,097 & 0,999 & \\
\hline $\mathrm{CS} 2$ & $\begin{array}{l}3,1 \\
1\end{array}$ & 1,238 & 0,545 & \\
\hline $\mathrm{CS} 3$ & $\begin{array}{l}3,8 \\
4 \\
\end{array}$ & 1,016 & 0,999 & \\
\hline Experience & & & & 0,492 \\
\hline EX1 & $\begin{array}{l}2,7 \\
6\end{array}$ & 1,481 & 0,356 & \\
\hline EX2 & $\begin{array}{l}3,0 \\
6\end{array}$ & 1,464 & 0,353 & \\
\hline EX3 & 4,0 & 1,092 & 0,010 & \\
\hline
\end{tabular}

\begin{tabular}{|l|l|l|l|l|}
\hline & 3 & & & \\
\hline Satisfaction & & & & 0,727 \\
\hline SF1 & $\begin{array}{l}3,9 \\
8\end{array}$ & 1,141 & 0,893 & \\
\hline SF2 & $\begin{array}{l}4,1 \\
1\end{array}$ & 1,010 & 0,809 & \\
\hline SF3 & $\begin{array}{l}3,9 \\
8\end{array}$ & 1,065 & 0,779 & \\
\hline $\begin{array}{l}\text { Perceived } \\
\text { Profit }\end{array}$ & $\begin{array}{l}4,0 \\
3\end{array}$ & 1,077 & 0,994 & \\
\hline PP1 & $\begin{array}{l}4,1 \\
0\end{array}$ & 1,020 & 0,862 & \\
\hline PP2 & $\begin{array}{l}4,1 \\
8\end{array}$ & 0,971 & 0,776 & \\
\hline PP3 & $\begin{array}{l}3,8 \\
8\end{array}$ & 1,117 & 0,955 & \\
\hline $\begin{array}{l}\text { Perceived } \\
\text { Ease of Use }\end{array}$ & $\begin{array}{l}3,9 \\
4\end{array}$ & 1,128 & 0,853 & \\
\hline PEU1 & $\begin{array}{l}4,0 \\
8\end{array}$ & 1,065 & 0,799 & \\
\hline PEU2 & $\begin{array}{l}4,1 \\
4\end{array}$ & 1,1 \\
PEU3 & 1,051 & 0,890 & \\
\hline PEU & $\begin{array}{l}3,5 \\
\text { System }\end{array}$ & 1,345 & 0,707 & \\
\hline US1 & 1,441 & 0,775 & \\
\hline IU1 & & 0,802 & \\
\hline IU2 & & & \\
\hline IU3 & & & \\
\hline Ese & & & \\
\hline
\end{tabular}

Elaborated: By the Author

\section{Testing the Hypotheses}

At this point, the Pre-Test (Gc) and Post-Test (Ge) samples were compared for the indicators defined in the previous points.

\section{Results for the Indicators}


Table 6. Pre-Test and Post-Test Results of the Dependent Variable Indicators.

\begin{tabular}{|c|c|c|c|c|c|c|c|c|c|c|c|c|}
\hline \multirow{5}{*}{$\begin{array}{l}\mathbf{N} \\
\mathbf{o}\end{array}$} & \multicolumn{2}{|c|}{ I1: } & \multicolumn{2}{|c|}{ I2: } & \multicolumn{2}{|c|}{ I3: } & \multicolumn{2}{|c|}{ I4: } & \multicolumn{2}{|c|}{ I5: } & \multicolumn{2}{|c|}{ I6: } \\
\hline & $\mathbf{P}$ & $\mathbf{P}$ & $\mathbf{P}$ & $\mathbf{P}$ & $\mathbf{P}$ & $\mathbf{P}$ & $\mathbf{P}$ & $\mathbf{P}$ & $\mathbf{P}$ & $\mathbf{P}$ & & $\mathbf{P}$ \\
\hline & $\mathbf{R}$ & O & $\mathbf{R}$ & 0 & $\mathbf{R}$ & 0 & $\mathbf{R}$ & $\mathbf{O}$ & $\mathbf{R}$ & $\mathbf{O}$ & $\mathbf{R}$ & O \\
\hline & $\mathbf{E}$ & S & $\mathbf{E}$ & $\mathbf{S}$ & $\mathbf{E}$ & $\mathbf{S}$ & $\mathbf{E}$ & $\mathbf{S}$ & $\mathbf{E}$ & $\mathbf{S}$ & $\mathbf{E}$ & $\mathbf{S}$ \\
\hline & & & & & & & & & & & & \\
\hline 1 & 3 & $\begin{array}{l}1 \\
5\end{array}$ & $\begin{array}{l}2 \\
2\end{array}$ & 1 & $\begin{array}{l}1 \\
4\end{array}$ & 1 & $\begin{array}{l}2 \\
0\end{array}$ & 2 & 3 & $\begin{array}{l}2 \\
3\end{array}$ & 2 & $\begin{array}{l}2 \\
0\end{array}$ \\
\hline 2 & 4 & 1 & 2 & 3 & 7 & 3 & 1 & 6 & 7 & 2 & 6 & 2 \\
\hline & & 2 & 8 & & & & 7 & & & 7 & & 6 \\
\hline 3 & 6 & 1 & 2 & 4 & 1 & 4 & 1 & 8 & 5 & 1 & 7 & 2 \\
\hline & & 6 & 6 & & 5 & & 6 & & & 4 & & 4 \\
\hline 4 & 8 & 1 & 2 & 1 & 1 & 1 & 1 & 1 & 8 & 1 & 8 & 2 \\
\hline & & 8 & 8 & & 5 & & 8 & & & 6 & & 6 \\
\hline 5 & 7 & 1 & 1 & 3 & 1 & 3 & 1 & 3 & 3 & 1 & 3 & 2 \\
\hline & & 7 & 1 & & 1 & & 3 & & & 8 & & 8 \\
\hline 6 & 3 & 1 & 2 & 6 & 4 & 6 & 1 & 6 & 6 & 1 & 6 & 2 \\
\hline & & 3 & 4 & & & & 9 & & & 9 & & 9 \\
\hline 7 & 2 & 6 & 2 & 1 & 1 & 1 & 1 & 1 & 4 & 1 & 5 & 2 \\
\hline & & & 9 & & 5 & & 5 & & & 5 & & 5 \\
\hline 8 & 4 & 9 & 2 & 7 & 1 & 7 & 1 & 7 & 1 & 2 & 2 & 2 \\
\hline & & & 5 & & 2 & & 2 & & & 5 & & 7 \\
\hline 9 & 5 & 1 & 2 & 9 & 1 & 9 & 1 & 2 & 2 & 2 & 3 & 2 \\
\hline & & 0 & 7 & & 1 & & 1 & & & 1 & & 1 \\
\hline 1 & 2 & 1 & 2 & 2 & 1 & 1 & 1 & 4 & 4 & 2 & 4 & 2 \\
\hline 0 & & 5 & 8 & & 2 & & 0 & & & 0 & & 9 \\
\hline 1 & 7 & 1 & 1 & 7 & 7 & 7 & 1 & 7 & 3 & 2 & 2 & 2 \\
\hline 1 & & 7 & 4 & & & & 4 & & & 7 & & 6 \\
\hline 1 & 4 & 1 & 2 & 2 & 3 & 2 & 1 & 2 & 2 & 2 & 3 & 2 \\
\hline 2 & & 4 & 6 & & & & 5 & & & 5 & & 7 \\
\hline 1 & 8 & 1 & 2 & 5 & 1 & 5 & 1 & 3 & 3 & 2 & 4 & 2 \\
\hline 3 & & 8 & 5 & & 1 & & 8 & & & 8 & & 8 \\
\hline 1 & 5 & 1 & 2 & 3 & 1 & 5 & 1 & 4 & 4 & 2 & 5 & 2 \\
\hline 4 & & 5 & 3 & & 7 & & 6 & & & 6 & & 7 \\
\hline 1 & 4 & 1 & 2 & 2 & 1 & 3 & 1 & 3 & 8 & 2 & 7 & 2 \\
\hline 5 & & 4 & 8 & & 5 & & 2 & & & 2 & & 3 \\
\hline 1 & 1 & 1 & 2 & 5 & 6 & 2 & 1 & 2 & 2 & 2 & 6 & 2 \\
\hline 6 & & 2 & 5 & & & & 9 & & & 9 & & 8 \\
\hline 1 & 9 & 1 & 2 & 3 & 3 & 5 & 1 & 1 & 1 & 2 & 1 & 2 \\
\hline 7 & & 1 & 7 & & & & 1 & & & 9 & & 9 \\
\hline 1 & 2 & 8 & 2 & 6 & 3 & 3 & 6 & 3 & 7 & 2 & 8 & 2 \\
\hline 8 & & & 4 & & & & & & & 6 & & 6 \\
\hline 1 & 3 & 5 & 2 & 5 & 8 & 6 & 8 & 3 & 3 & 2 & 3 & 2 \\
\hline 9 & & & 6 & & & & & & & 4 & & 4 \\
\hline 2 & 2 & 7 & 3 & 3 & 5 & 5 & 5 & 5 & 5 & 2 & 5 & 2 \\
\hline 0 & & & 0 & & & & & & & 3 & & 8 \\
\hline 2 & 3 & 1 & 2 & 5 & 1 & 5 & 1 & 1 & 1 & 2 & 2 & 2 \\
\hline 1 & & 3 & 8 & & 1 & & 2 & & & 2 & & 9 \\
\hline 2 & 2 & 1 & 2 & 3 & 1 & 3 & 1 & 3 & 3 & 2 & 3 & 2 \\
\hline 2 & & 2 & 2 & & 4 & & 3 & & & 3 & & 6 \\
\hline 2 & 1 & 1 & 2 & 5 & 9 & 5 & 1 & 5 & 8 & 2 & 7 & 2 \\
\hline 3 & & 1 & 7 & & & & 5 & & & 5 & & 5 \\
\hline
\end{tabular}

\begin{tabular}{|l|l|l|l|l|l|l|l|l|l|l|l|l|}
\hline 2 & 6 & 1 & 1 & 2 & 9 & 2 & 1 & 2 & 2 & 2 & 2 & 2 \\
4 & & 6 & 3 & & & & 1 & & & 7 & & 7 \\
\hline 2 & 5 & 1 & 1 & 4 & 3 & 4 & 1 & 4 & 4 & 2 & 4 & 2 \\
5 & & 9 & 4 & & & & 3 & & & 6 & & 4 \\
\hline 2 & 3 & 1 & 1 & 3 & 9 & 3 & 1 & 3 & 3 & 2 & 3 & 2 \\
6 & & 4 & 9 & & & & 9 & & & 9 & & 9 \\
\hline 2 & 1 & 1 & 2 & 4 & 1 & 4 & 1 & 4 & 4 & 2 & 6 & 2 \\
7 & & 7 & 9 & & 0 & & 0 & & & 8 & & 8 \\
\hline 2 & 2 & 1 & 2 & 2 & 1 & 2 & 1 & 2 & 6 & 1 & 1 & 2 \\
8 & & 2 & 2 & & 7 & & 8 & & & 8 & 2 & 4 \\
\hline 2 & 5 & 1 & 2 & 6 & 1 & 6 & 1 & 4 & 4 & 2 & 4 & 2 \\
9 & & 5 & 5 & & 8 & & 5 & & & 5 & & 5 \\
\hline 3 & 4 & 1 & 2 & 8 & 1 & 8 & 1 & 2 & 5 & 2 & 3 & 2 \\
0 & & 8 & 6 & & 3 & & 4 & & & 4 & & 7 \\
\hline
\end{tabular}

Elaborated: By the Author

The approaches of the indicator hypothesis are detailed below:

\section{Contrast for research indicators}

- Contrast for the time to develop an evaluation: I1

The impact of the Implementation of Information and Communication Technologies must be validated, if the number of technological resources in the laboratories of the faculties of the Technical University of Cotopaxi, carried out in the sample, will be increased. One measurement is made before the model implementation (Pre-Test) and another after the model implementation (Post-Test).

The table contains the times for the development of the material for the two samples:

Table 7. Measurement of the model for the implementation of the model.

\begin{tabular}{|l|l|l|l|l|l|l|l|l|l|l|}
\hline $\begin{array}{l}\text { Pre- } \\
\text { Test }\end{array}$ & 3 & 4 & 6 & 8 & 7 & 3 & 2 & 4 & 5 & 2 \\
\hline \multirow{5}{*}{} & 7 & 4 & 8 & 5 & 4 & 1 & 9 & 2 & 3 & 2 \\
\cline { 2 - 10 } & 3 & 2 & 1 & 6 & 5 & 3 & 1 & 2 & 5 & 4 \\
\cline { 2 - 9 }
\end{tabular}

\begin{tabular}{|l|l|l|l|l|l|l|l|l|l|l|}
\hline $\begin{array}{l}\text { Post- } \\
\text { Test }\end{array}$ & 15 & 12 & 16 & 18 & 17 & 13 & 6 & 9 & 10 & 15 \\
\hline \multirow{4}{*}{} & 17 & 14 & 18 & 15 & 14 & 12 & 11 & 8 & 5 & 7 \\
\cline { 2 - 10 } & 13 & 12 & 11 & 16 & 19 & 14 & 17 & 12 & 15 & 18 \\
\hline
\end{tabular}

Elaborated: By the Author

H1: If Information and Communication Technologies are implemented, the number of technological resources will increase.

H1: $\mu 1<\mu 2$ 


\section{Solution:}

\section{a) Statement of the Hypothesis:}

$\boldsymbol{\mu 1}=$ Average time of material development in the Pre-Test.

$\boldsymbol{\mu 2}=$ Average time of material development in the Post-Test.

H0: $\mu 1 \geq \mu 2$

Ha: $\mu 1<\mu 2$

\section{b) Decision Criteria}

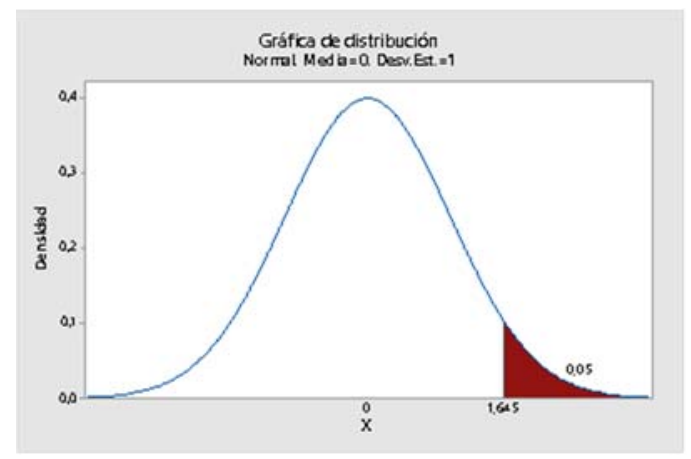

Fig. 1 Implementation of Information and Communication Technologies

c) Calculation: t-test for measurements of samples I1

Table 8. Descriptive Statistics

\begin{tabular}{|l|l|l|l|l|}
\hline Shows & & Half & & $\begin{array}{l}\text { Error } \\
\text { standard } \\
\text { of the } \\
\text { half }\end{array}$ \\
\hline Post Test & 30 & 13,30 & 3,73 & 0,68 \\
\hline Pre Test & 30 & 4,03 & 2,22 & 0,41 \\
\hline
\end{tabular}

Elaborated: By the Author

Table 9. Estimation of the difference

\begin{tabular}{|l|l|l|}
\hline & \multicolumn{1}{|l|}{$\begin{array}{l}\text { Upper limit } \\
95 \% \text { for } \\
\text { difference }\end{array}$} \\
\hline 9,267 & \multicolumn{1}{|l}{10,597} \\
\hline Value T & GL & Value $\mathrm{p}$ \\
\hline 11,68 & 47 & 1,000 \\
\hline
\end{tabular}

Elaborated: By the Author

\section{Author's discussion}

Since the p-value $=0.000<a=0.05$, the results provide enough evidence to reject the null hypothesis (H0), and the alternate hypothesis (Ha) is true. The test turned out to be significant.

The researcher [18], mentions some of the important Web 2.0 tools that must have as fundamental characteristics of virtual environments for teaching-learning:

- Content distribution tools. Teachers must provide an area for the student to have systematic information in the form of files and folders that can have different formats (HTML, PDF, DOCX, ODT, XLSX, GIF, ...) and metadata must be obtained to present content and relevant information: links to online files, Web pages, calendars, labels with various objectives (text, images, presentations, reports, videos).

- Synchronous and asynchronous communicationcollaboration tools: so that individuals in a training activity have to communicate and work regularly, such as discussion forums and information exchange, group chat, news, course messaging, blogs, wikis, among others.

- Performance and evaluation tools: such as adaptable questionnaires by the teacher for the evaluation of the students and with qualifications at that moment of the individual and group tasks, for the teacher reports on the tasks of each student.

- Management tools and assignment of userprofiles: that make it possible to assign permissions within each subject to be taught, access profiles. These changes can be made at the administrator level, but also at the tutor profile and student level.

- Additional tools: Some platforms have a portfolio, syllabus, search tools within the subject in forums, among others; depending on the LMS applied and on which web platform it is compatible.

In our research, there are several examples of LMS such as WebCT, Moodle, Black Board, Moodle, Whiteboard, Web Board, Web Course in a Box, Claroline, Net Campus, Phoenix Pathlore, Profe, Saba, Symposium, Angel, Sakai, and Moodle, among others.

The researcher [33], propose to design a new TAM model specifically designed to explain the acceptance of students and teachers within higher education institutions by applying innovation technologies.

The proposal will be created from the TAM model and expanded with constructors of other models, such as TRA, TPB, UTAUT, IDT or TAM3.

Concerning this, there is little research on the TAM model in educational institutions; in emerging 
economies in South America, only 3 relevant academic articles have been found in our research, which suggests that we delve further into the TAM model and its variants that allow us to carry out a validity and verification in our environment of the model through improvement proposals according to the ICT tools to be used.

The result is a complete theoretical model that integrates the constructors considered the most relevant to explain the process of adopting a technology: PU, PEOU, BI, ATT, SN, AU, SE, FC, PP, ANX, PK, SAT, TS and CSE, which are the most widely used, which in Chapter 3 was designed for the collaborative environment in universities.

The Times Higher Education World University Rankings is a global research accompanied by the rating of the best higher education institutions of global significance. It was calculated with the help of Times Higher Education (THE) methodology with the participation of Thomson Reuters information group. This rating is one of the most influential global ratings of universities. It was developed in 2010 by Times Higher Education in cooperation with Thomson Reuters in terms of Global Institutional Profiles Project and was the successor of the popular World University Rankings, issued by Times Higher Education in collaboration with Quacquarelli Symonds company. In its turn, since 2010, Quacquarelli Symonds has been issuing the rating world's best universities under the name of QS World University Rankings that is also considered to be one of the most prominent in this field. According to the methodology of THE World University Rankings, the level of accomplishments of HEI (higher education institutions) is assessed on the grounds of their results in the combination of statistical analysis of their activities, audited data, as well as of the results of annual expert polling of the representatives of international academic community and employers that express their thoughts about a higher education institution. In [34] an Information Technology Knowledge Management System is presented about the Interaction of Educational and ScientificProduction Structures.

\section{Conclusions}

- Using ICTs online offers many opportunities for information exchange and collaboration for students and learning. Furthermore, this study focused solely on students; it is necessary to implement research with university teachers. Its adoption processes should be taken into account when designing an elearning support program with CLE, in developing countries such as the United States, Colombia, Peru, Ecuador, Argentina, Chile and in developed countries on the Asian continent. And European.

- From the results obtained in the different statistical calculation tools, it arrived at the determination that the software proposed in the investigation can be executed and applied in the different dependencies and laboratories of the Technical University of Cotopaxi to search for the best work and student performance in all levels of the undergraduate and postgraduate student preparation.

- The study carried out of a systematic review of all the models that have been appearing through the different studies carried out in the different countries of the world and that have been applied in the different public and private institutions, in public and private universities, have contributed in the improvement of the teaching-learning process, in this particular case the degree of satisfaction, use of the system, perceived ease of use, perceived utility, the expectation of system performance, perceived entertainment, social factor, the condition will be measured facilitator, teamwork, technical support, computational self-reliance, and experience through the use of the system, these are some of the achievements achieved with the use of the system proposed by the researcher at the university where he works.

- The indicators are contrasted to check the variables and thus carry out the construction of the model proposed by the researcher and thus provide a better service in all the academic requirements proposed in the survey carried out on students from the different faculties of the Technical University of Cotopaxi. 


\section{References:}

[1] Davis, F.D. A technology acceptance model for empirically testing new end-user information systems: theory and results. $\mathrm{PhD}$ Thesis, Sloan School of Management, Massachusetts Institute of Technology, 1986

[2] Ahumada, M. Innovando la docencia y la evaluación: las herramientas 2.0 al aula. Actual. Pedagog, 60(2), 15-28. 2012

[3] Chen, F. H., Looi, C. K., y Chen, W. . Integrating technology in the classroom: A visual conceptualization of teachers' knowledge, goals and beliefs. Journal of Computer Assisted Learning, 25(5), 470-488, 2009 https://doi.org/10.1111/j.1365-2729.2009.00323.x

[4] Barak, M., y Ziv, S. Wandering: A Web-based platform for the creation of location-based interactive learning objects. Computers \& Education, $\quad 62, \quad 159-170, \quad 2013$ https://doi.org/10.1016/j.compedu.2012.10.015.

[5] Nagy, T. J., Using learning management systems in business and economics studies in Hungarian higher education. Education and Information Technologies, 21(4), 897-917, 2016 https://doi.org/10.1007/s10639-014-9360-6.

[6] Hirsch, B., Hitt, G.W., Powell, L., Khalaf, K., y Balawi, S., Collaborative learning in action. Proceedings of the IEEE International Conference on Teaching, Assess-ment and Learning for Engineering, Bali, Indonesia. 2013

[7] Sierra, Á.L. ¿Cómo implantar el Gobierno de las Tecnologías de Información en Instituciones de Educación Superior?. (Tesis de Maestría), Colombia: Departamento Académico de Tecnologías de Información y Comunicaciones, Facultad de Ingeniería, Universidad ICESI, 2012

[8] Nuñez, E., Penelas, A., y Cuesta, P. El desarrollo de web 3.0 como innovación en la docencia de comercialización e investigación de mercados. Caracciolos: revista digital de investigación en docencia, 2(1), 1-10, 2013

[9] García-Riaza, B., y Iglesias, A. Attitude towards the use of mobile devices for the practice of oral skills in English. In Proceedings of the Second International Conference on Technological Ecosystems for Enhancing Multiculturality (Salamanca, España, October 01-03, 2014, TEEM'14. ACM, New York, N.Y., USA. https://doi.org /10.1145/2669711.2669928.

[10] Iglesias, A., Sánchez, M. C., y Pedrero, C. Case study on collaborative work experiences with web 2.0 in Spanish Primary Schools with the Highest Institutional accreditation level. Journal of Cases on Information Technology, 16(3), 33-50, 2014 https://doi.org/10.4018/JCIT.2014070104.

[11] Iglesias-Rodríguez, A., y García-Riaza, B. Learning Goes Mobile: Devices and Apps for the Practice of Contents at Tertiary Level. In D. Fonseca and E. Redondo (Eds.), Handbook of Research on Applied E-Learning in Engineering and Architecture Education (472-496). Hershey, PA: Engineering Science Reference. 2016 https://doi.org/10.4018/978-1- 4666-8803-2.ch021. [12] Naismith, L., Lonsdale, P., Vavoula, G. y Sharples, M. . Literature review in mobile technologies and learning. Futurelab series, Report 11, University of Birmingham, 2004

[13]Traxler, J., Learning in a mobile age. International Journal of Mobile and Blended Learning 1(1), 1-12, 2009

[14] Ferdig, R., Cavanaugh, C., y Freidhoff, J. Research into K-12 online learning. In Clark, T. y Barbour, M. (Eds.), Online and distance education in schools: Global perspectives on policy and practice. Sterling, VA: Stylus and Microsoft, 2015 https://sty.presswarehouse.com/Books/BookDetail. aspx? productID $=391638$

[15] Cavanaugh, C., Sessums, C., y Drexler, W., A call to action for research in digital learning: Learning without limits of time, place, path, pace...or evidence. Journal of Online Learning Research, 1(1) 9-15, 2015

[16] Virtanen, J., y Rasi, P., Integrating Web 2. 0 Technologies into Face-to-Face PBL to Support Producing, Storing, and Sharing Content in a Higher Education Course The Interdisciplinary Journal of Problem-based Learning Voices from the Field Integrating Web 2. 0 Technologies int. Interdisciplinary Journal of Problem-Based Learning, 11(1), 2017

[17] Watson, W.R., y Watson, S.L., What are Learning Management Systems, What are They Not, and What Should They Become? TechTrends, 51(2), 29, 2007

[18] Sánchez-Olavarría, C., B-learning como estrategia para el desarrollo de competencias. El caso de una universidad privada. Revista Iberoamericana De Educación, 67(1), 85-100, 2014 [19] Vicheanpanya, J., E-Learning Management System Model for Thai Society. International Journal of Information and Education Technology, 4(1), 67-70. 2014, http://dx.doi.org/10.7763/IJIET.2014.V4.371.

[20] Ramakrisnan, P., Jaafar, A., Razak, H.A., y Ramba, D.A., Evaluation of user Interface Design for Leaning Management System (LMS): 
Investigating Student's Eye Tracking Pattern and Experiences. Procedia - Social and Behavioral Sciences, 67(0), 527-537, 2012 http://dx.doi.org/10.1016/j.sbspro.2012.11.357.

[21] Cormier, D., The CCK08 MOOC Connectivism course, 1/4 way. Dave's Educational Blog. Disponible en: http://davecormier.com/edblog/2008/10/02/thecck08-mooc-connectivism-course14-way/. 2008 [22]Markoff (2011). Virtual and Artificial, but 58,000 Want Course. Recuerado el 10 de Marzo de 2018 de http://www.nytimes.com/2011/08/16/science/16sta nford.html? r=1\&.

[23] Armstrong, L. 2013- the Year of Ups and Downs for the MOOCs. Changing Higher Education. Recuperado de http://goo.gl/SqwGWn. 2014

[24] Pineda-Martínez, P., y Castañeda-Zumeta, A., Los LMS como herramienta colaborativa en educación: Un análisis comparativo de las grandes plataformas a nivel mundial. $\mathrm{V}$ Congreso Internacional Latina de Comunicación Social - V CILCS - Universidad de La Laguna, 1-13, 2013

[25] Niño, J. , Tareas de Administración lll. En Sistemas operativos en red. Madrid: Editex, 2011

[26] Valdivia, C. , Sistemas informáticos y redes locales. Madrid: Paraninfo S.A., 2005

[27] Haro, J.J., Redes Sociales para la Educación. Editorial Anaya Multimedia, 2010

[28] Valenzuela, R., Las redes sociales y su aplicación en la educación. Revista Digital, 2013

[29] Peña, J.B., Fernández, E.A., Kirillof, S., y Tovar, N., La simulación y los juegos en línea como herramienta para la inmersión educativa. Revista Etic@net.9(10).1-10,2011

[30] Edrees, M.E., eLearning 2.0: Learning Management Systems Readiness. Paper presented at the e-Learning "Best Practices in Management, Design and Development of e-Courses: Standards of Excellence and Creativity", 2013 Fourth International Conference on

[31] Shaltout, A.F., y Bin Salamah, A.I., The Impact of Web 3.0 on E-Learning. Paper presented at the e-Learning "Best Practices in Management, Design and Development of e-Courses: Standards of Excellence and Creativity", 2013 Fourth International Conference on.

[32] Arias, F., El Proyecto de Investigación. Introducción a la metodología científica. (Sexta ed., Vol. VI). Caracas, Venezuela: Episteme, 2012

[33] Kanwal, F., \& Rehman, M., Factors Affecting E-Learning Adoption in Developing CountriesEmpirical Evidence from Pakistan's Higher Education Sector. IEEE Access, 5, 10968-10978,
2017,

https://doi.org/10.1109/ACCESS.2017.2714379.

[34] Batova Marina Mikhailovna, Baranova Irina Vyacheslavovna, Information Technology Knowledge Management in the System of Interaction of Educational and ScientificProduction Structures, WSEAS Transactions on Business and Economics, Volume 16, pp. 545-551, 2019. 